\title{
Peningkatan Pengetahuan dan Keterampilan Kader Posyandu dalam Pengukuran Antropometri di Kelurahan Cilandak Barat Jakarta Selatan
}

\author{
Anna Fitriani $^{{ }^{*}}$ dan Desiani Rizki Purwaningtyas ${ }^{1}$ \\ ${ }^{1}$ Fakultas Ilmu-Ilmu Kesehatan Universitas Muhammadiyah Prof. Dr. Hamka, Jl. Limau II No. 3, \\ RT.3/RW.3, Kramat Pela, Kby. Baru, Jakarta Selatan, 12210 \\ *Email Korespondensi: annafitriani@uhamka.ac.id
}

\begin{abstract}
Abstrak
Rendahnya pengetahuan dan keterampilan kader posyandu dalam pengukuran antropometri, mulai dari cara memasang dan menera alat ukur, menimbang, mengukur panjang badan, dan tinggi badan balita hingga mencatat hasil ukur berdampak pada pendataan dan pelaporan status gizi yang tidak akurat. Salah satu faktor penyebabnya adalah kurangnya penyuluhan dan pelatihan kepada kader posyandu. Oleh karena itu, program kemitraan masyarakat (PKM) ini memberikan solusi berupa penyuluhan dan pelatihan tentang pengukuran antropometri pada kader posyandu di Kelurahan Cilandak Barat. Pengetahuan dan keterampilan kader sebelum dan sesudah intervensi diukur. Hasil analisis menunjukkan peningkatan rata-rata skor pengetahuan (11,13 menjadi 14,67) dan skor keterampilan (26,59 menjadi 39,00) secara signifikan (p value =0,001). Hal ini menunjukkan bahwa penyuluhan dan pelatihan efektif meningkatkan pengetahuan dan keterampilan kader posyandu.
\end{abstract}

Kata kunci: Pengetahuan; keterampilan; antropometri; kader posyandu.

\begin{abstract}
The low level of knowledge and skills of posyandu cadres in anthropometric measurements impact on validity of nutritional status among infants and children aged 12 - 59 months. One of the contributing factors was the lack of training for Posyandu cadres. Therefore, this community partnership program provided a training program focused on anthropometric measurements among posyandu cadres in Cilandak Barat. Knowledge and skills of cadres before and after intervention are measured. The results showed a significant increase of knowledge score (11.13 to 14.67) and the skill score (26.59 to 39.00) ( $p$ value $=0.001)$. We concluded that the training program effectively increased the knowledge and skills of posyandu cadres.
\end{abstract}

Keywords: Knowledge; skill; anthropometry; posyandu cadres.

Format Sitasi: Fitriani, A., Purwaningtyas, D.R. (2020). Peningkatan Pengetahuan dan Keterampilan Kader Posyandu dalam Pengukuran Antropometri di Kelurahan Cilandak Barat Jakarta Selatan. Jurnal Solma, 09(2), 367-378. Doi: http://dx.doi.org/10.22236/solma.v9i2.4087

Diterima: 11 Desember 2019 | Revisi: 20 Agustus 2020 | Dipublikasikan: 30 Oktober 2020

(C) 2020 Oleh authors. Lisensi Jurnal Solma, LPPM-Uhamka, Jakarta. Artikel ini bersifat open access yang didistribusikan di bawah syarat dan ketentuan Creative Commons Attribution (CC BY) license. (http://creativecommons.org/licenses/by/4.0/).

\section{PENDAHULUAN}

Masalah gizi pada bayi dan balita seperti gizi kurang, gizi buruk dan anak pendek/stunting masih tinggi di Indonesia. Riset Kesehatan Dasar (RISKESDAS) RI tahun 2018 menunjukkan bahwa 1 dari 3 atau sebesar 30,8\% anak-anak Indonesia usia di bawah lima tahun (balita) memiliki status gizi pendek/stunting (Kemenkes, 2011b). Prevalensi balita gizi buruk dan kurang pada balita juga tidak menunjukkan penurunan yang berarti (19,6\% di tahun 2013 menjadi 17,7\% di tahun 2018) dan angka ini masih lebih tinggi dari 
target RPJMN yakni 17\% di tahun 2019 (Kemenkes, 2011a). Masalah gizi tersebut penting untuk diperhatikan karena menyumbang 54\% kematian bayi dan balita. Selain itu, status gizi pada bayi dan balita memengaruhi fungsi kognitif pada masa sekolah, produktivitas pada masa dewasa dan status kesehatan pada usia-usia selanjutnya (Rajagopalan, 2003).

Peraturan Menteri Kesehatan No. 66 Tahun 2014 tentang Pemantauan Pertumbuhan Anak menegaskan pentingnya deteksi dini masalah gizi bayi dan balita melalui pemantauan pertumbuhan, yang salah satunya dapat dilakukan di pos pelayanan terpadu (posyandu). Sejak diluncurkan pada tahun 1970 dan direvitalisasi pada tahun 2001, posyandu saat ini masih menjadi program andalan pemerintah dalam mengentaskan masalah gizi dan mencegah kematian pada bayi dan balita. Sebagai upaya kesehatan bersumberdaya masyarakat, posyandu memiliki fungsi vital dalam pemantauan pertumbuhan anak dengan dilakukannya pengukuran antropometri setiap bulannya (Kemenkes, 2011a). Hasil pengukuran antropometri tidak hanya menjadi informasi bagi masyarakat (ibu) mengenai status gizi dan pertumbuhan anaknya, tetapi juga akan masuk ke dalam pelaporan terpadu puskesmas yang selanjutnya akan menjadi dasar kebijakan bagi pemerintah daerah dan pusat dalam menyelesaikan masalah gizi (Kemenkes, 2011b).

Namun harapan pemerintah untuk mendapatkan data yang akurat dari hasil pemantauan pertumbuhan di posyandu terbentur dengan rendahnya pengetahuan dan keterampilan kader posyandu dalam melakukan pengukuran antropometri. Penelitian Rahayu (2017) di Posyandu Kelurahan Karangasem Yogyakarta menunjukkan bahwa hampir separuh (45,8\%) kader memiliki pengetahuan yang kurang mengenai pengukuran antropometri. Hal ini berpengaruh signifikan terhadap rendahnya keterampilan kader, di mana 25\% kader memiliki keterampilan kurang dalam pengukuran antropometri ( $\mathrm{p}$ value=0,019). Penelitian Indriaty (2002) di Bogor, Sukabumi, Demak dan Semarang menunjukkan bahwa hampir seluruh kader (97,5\%) tidak akurat dalam menimbang. Selanjutnya pada tahun 2007 ditemukan bahwa lebih dari separuh kader (62,5\%) di 7 posyandu di Kecamatan Tempuran, Karawang tidak menimbang sesuai prosedur (Sukiarko, 2007). Sejalan dengan itu, Mahmudiono (2007) menemukan bahwa di beberapa wilayah sebanyak 61\% kader kurang teliti dan 97\% kader tidak akurat dalam penimbangan. Penelitian Sutiani (2014) di wilayah kerja Puskesmas Desa Lalang menunjukkan bahwa lebih dari separuh kader $(66,1 \%)$ kurang terampil dalam pemantauan pertumbuhan, di mana masih banyak kader yang menimbang balita tidak dengan pakaian seminimal mungkin.

Salah satu penyebab masih rendahnya pengetahuan dan keterampilan kader posyandu terkait pengukuran antropometri adalah kurangnya dukungan dalam bentuk pelatihan. Meskipun telah direvitalisasi pada tahun 2001, dengan adanya desentralisasi maka dukungan kepada posyandu tidak lagi terpusat melainkan bergantung pada komitmen pemerintah daerah. Hal ini menyebabkan pelatihan kader masih bersifat sporadis (Iswarawanti, 2010). Mengingat pemerintah masih mengandalkan posyandu dalam upaya pengentasan masalah gizi dan penurunan angka kematian bayi dan balita, maka pelatihan kader posyandu mutlak diperlukan (Iswarawanti, 2010).

Beberapa penelitian eksperimental pre-post design membuktikan peningkatan pengetahuan dan keterampilan kader setelah penyuluhan dan pelatihan terkait pemantauan pertumbuhan. Penelitian Laraeni \& Wiratni (2014) di wilayah kerja Puskesmas Dasan 
Cermen Mataram menunjukkan bahwa proporsi kader dengan pengetahuan baik meningkat dari 5\% menjadi 39\% setelah dilakukan penyegaran mengenai penimbangan dengan dacin. Penelitian Sianturi, (2013) di wilayah kerja Puskesmas Jatinegara menunjukkan adanya peningkatan signifikan rata-rata skor pengetahuan $(12,68$ menjadi 36 ; $p$ value $=0,000)$ dan keterampilan (8,23 menjadi 9,59; p value=0,013) pada kelompok perlakuan setelah pelatihan. Penelitian Lubis, Zulhaida, \& Syahri (2015) di wilayah kerja Puskesmas Desa Lalang dan Tuntungan Kota Medan menunjukkan peningkatan signifikan rata-rata skor pengetahuan sebesar 2428 point ( $p$ value $=0,0001$ ) dan keterampilan sebesar 1071 point ( $\mathrm{p}$ value $=0,003$ ).

Melihat masih rendahnya tingkat pengetahuan dan keterampilan kader dalam hal pemantauan pertumbuhan di berbagai daerah di Indonesia, maka bukan tidak mungkin hal yang sama terjadi di Ibu Kota Jakarta. Penelitian terbaru oleh Gandaasri (2017) di wilayah kerja Puskesmas Kelurahan Pesanggrahan Jakarta Selatan diperoleh bahwa 100\% kader tidak menimbang dengan akurat. Padahal, data penimbangan tersebut akan dilanjutkan ke tingkat kecamatan, dinas kesehatan dan seterusnya sebagai dasar kebijakan program gizi. Hal inilah yang mendorong dilakukannya penyuluhan dan pelatihan kader posyandu di Jakarta Selatan, yakni di wilayah kerja Puskesmas Kelurahan Cilandak Barat. Puskesmas Cilandak Barat membawahi 12 posyandu dengan jumlah kader aktif seluruhnya berjumlah 77 orang. Semua posyandu di kelurahan ini secara rutin melaporkan data hasil pemantauan pertumbuhan bayi dan balita setiap bulan. Survei pendahuluan menunjukkan bahwa umumnya kader baru 1 kali mendapatkan pelatihan mengenai pengukuran antropometri. Melihat permasalahan tersebut maka sangat tepat apabila program kemitraan masyarakat ini membidik peningkatan pengetahuan dan keterampilan kader posyandu dalam pengukuran antropometri di Kelurahan Cilandak Barat Jakarta Selatan. Diharapkan kegiatan ini dapat meningkatkan pengetahuan dan keterampilan kader posyandu dalam melaksanakan pengukuran antropometri.

\section{MASALAH}

Pengetahuan dan keterampilan kader posyandu dalam melaksanakan antropometri masih rendah. Masalah ini terjadi di hampir seluruh kota di Indonesia seperti: Yogyakarta (Rahayu, 2017), Demak, Semarang, Sukabumi, Bogor (Indriaty, 2002) dan Karawang (Sukiarko, 2007). Hal ini disebabkan pelatihan kader posyandu di Indonesia masih bersifat sporadis (Iswarawanti, 2010). Penelitian terbaru oleh (Gandaasri, 2017) di wilayah kerja Puskesmas Kelurahan Pesanggrahan Jakarta Selatan diperoleh bahwa 100\% kader tidak menimbang dengan akurat. Survei pendahuluan pada kader posyandu di wilayah kerja Puskesmas Keluarahan Cilandak Barat menunjukkan bahwa umumnya kader baru 1 kali mendapatkan pelatihan mengenai pengukuran antropometri.

Salah satu solusi yang secara nyata terbukti meningkatkan pengetahuan dan keterampilan kader posyandu dalam pengukuran antropometri adalah dengan memberikan pelatihan yang intensif bagi kader. Pelatihan kader di beberapa kota seperti Mataram (Laraeni \& Wiratni, 2014), Medan (Lubis et al., 2015), dan Jakarta (Sianturi, 2013) terbukti meningkatkan pengetahuan dan keterampilan kader dalam menimbang dan mengukur balita. Rumusan inilah yang melatarbelakangi dilaksanakannya kegiatan pengabdian masyarakat 
dengan melatih kader posyandu yang bertujuan meningkatkan pengetahuan dan keterampilan mereka dalam pengukuran antropometri.

\section{METODE PELAKSANAAN}

\section{Desain Studi}

Penelitian ini menggunakan metode eksperimen semu (quasi experimental design) dengan rancangan non-randomized pretest - postest design. Dengan dilaksanakannya PKM berupa penyuluhan dan pelatihan, maka peneliti ingin mengetahui peningkatan pengetahuan dan keterampilan kader posyandu dalam melakukan pengukuran antropometri pada bayi dan balita di Kelurahan Cilandak Barat Jakarta Selatan.

\section{Sebjek Penelitian}

Sebanyak 15 kader dari Posyandu Kenanga 1 dan Kenanga 2 diberikan penyuluhan dan pelatihan selama sehari. Narasumber penyuluhan dan pelatihan yakni Anna Fitriani, M.K.M., Desiani Rizki, M.Si. dan Izna Nurdiyanti, M.Si. yang telah membuat kuesioner pretest-postest serta media edukasi berupa presentasi dan booklet. Kader memenuhi kriteria inklusi, yakni telah bekerja sebagai kader minimal 6 bulan.

\section{Lokasi, Waktu dan Durasi Kegiatan}

Penyuluhan dan pelatihan bertempat di RPTRA Intan Kelurahan Cilandak Barat Jakarta Selatan. Kegiatan ini berlangsung pada 20 Februari - 24 Mei 2018. Pretest pengetahuan dan keterampilan dilaksanakan pada tanggal 27 Februari 2018. Penyuluhan dan pelatihan berlangsung dari tanggal 27 - 15 Mei 2018. Posttest pengetahuan dan keterampilan dilaksanakan pada tanggal 18 Mei 2018. Evaluasi dan monitoring dilaksanakan pada tanggal 19 - 24 Mei 2018.

\section{Teknik Pengumpulan Data}

Pengumpulan data primer pre-posttest pengetahuan dikumpulkan dengan instrumen kuesioner pengetahuan yang terdiri dari 20 pertanyaan. Seluruhnya merupakan pertanyaan terkait cara pengukuran antropometri pada bayi dan balita, mulai dari jenis alat, cara memasang alat, cara memperlakukan responden, cara mengukur hingga cara membaca dan mencatat hasil pengukuran. Peserta yang berjumlah 15 orang melaksanakan pretest pengetahuan secara self-assessment di mana kader menjawab sendiri soal pretest dengan bantuan instruktur. Setiap 1 jawaban benar diberi skor 1 dan jawaban salah diberi skor 0 . Pengetahuan dikategorikan menjadi dua, yakni: 1) baik apabila responden menjawab $\geq 60 \%$ atau memiliki skor $\geq 12$ soal benar; 2) kurang apabila responden menjawab $<60 \%$ atau memiliki skor $<12$ (Arikunto, 2002).

Pengumpulan data primer pre-posttest keterampilan menggunakan instrumen daftar tilik observasi yang pernah digunakan dalam penilaian keterampilan kader posyandu di Jakarta Utara oleh Tim Positive Deviance Resource Centre Universitas Indonesia (PDRC UI). Daftar tilik ini terdiri dari tahapan pengukuran mulai dari pemasangan alat, perlakuan terhadap responden, pembacaan dan pencatatan hasil ukur seperti ditunjukkan tabel 1. Daftar tilik observasi ini terdiri dari 5 jenis pengukuran antropometri dengan dasar penetapan skor sebagai berikut.

1. Penimbangan berat badan bayi menggunakan baby scale. Pengukuran ini terdiri dari 6 langkah, yakni 1 langkah pada tahap pemasangan alat dan 5 langkah pada tahap 
pengukuran. Keenam langkah tersebut antara lain: 1) pemasangan alat pada bidang datar; 2) memastikan angka nol pada baby scale; 3) memastikan bayi menggunakan pakaian seminimal mungkin; 4) memposisikan seluruh badan bayi di atas timbangan; 5) membaca angka yang muncul di monitor 6) mencatat hasil penimbangan hingga ketelitian 0,1 kg. Apabila kader dapat mempraktikkan seluruh langkah dengan tepat maka mendapakan skor 6 .

2. Penimbangan berat badan balita menggunakan dacin. Pengukuran ini terdiri dari 12 langkah, yakni 7 langkah pada tahap pemasangan alat dan 5 langkah pada tahap pengukuran. Ketujuh langkah pada tahap pemasangan alat antara lain: 1) menggantung dacin pada tempat yang kokoh; 2) memastikan dacin tergantung dengan kuat; 3) meletakkan bandul geser pada angka nol; 4) mengatur posisi angka pada batang dacin sejajar dengan mata penimbang; 5) memastikan bandul geser pada angka nol; 6) memasang sarung timbang yang kosong pada dacin; 7) menyeimbangkan dacin yang sudah dibebani sarung timbang dengan menggantungkan kantong berisi beras atau pasir dan sejenisnya hingga batang hingga kedua jarum tegak lurus. Kelima langkah pada tahap pengukuran antara lain: 1) memasukkan balita ke sarung timbang dengan pakaian seminimal mungkin; 2) menggeser bandul hingga jarum setimbang; 3) membaca angka yang berhimpit dengan bandul geser sebagai berat badan alita; 4) mencatat berat badan balita hingga ketelitian 0,1 kg; 5) mengembalikan bandul geser ke angka nol.

3. Penimbangan berat badan balita menggunakan timbangan injak. Pengukuran ini terdiri dari 7 langkah, yakni 1 langkah pada tahap pemasangan alat dan 6 langkah pada tahap pengukuran. Ketujuh langkah tersebut antara lain: 1) meletakkan timbangan injak pada bidang datar; 2) memastikan jarum timbangan di angka nol sebelum digunakan; 3) memastikan balita berpakaian seminimal mungkin dan tidak menyimpan apa pun di kantong bajunya; 4) meminta balita untuk naik ke timbangan injak dengan posisi kaki di tengah timbangan dan pandangan matanya lurus ke depan; 5) melihat angka yang ditinjukkan oleh jarum saat jarum sudah berhenti bergerak-gerak; 6) mencatat berat badan balita.

4. Pengukuran panjang badan bayi dan balita yang belum bisa berdiri mengggunakan length board. Pengukuran ini terdiri dari 10 langkah, yakni 1 langkah pada tahap pemasangan alat dan 9 langkah pada tahap pengukuran. Kesembilan langkah tersebut antara lain: 1) meletakkan papan pengukur pada bidang datar; 2) pengukur memposisikan diri pada bagian papan yang terdapat pita ukur (bagian kaki) dan asisten di bagian kepala; 3) memastikan balita berpakaian seminimal mungkin; 4) meminta ibu balita meletakkan balita di papan pengukur dengan posisi kepala dan kaki yang tepat; 5) memposisikan puncak kepala balita sedemikian sehingga menempel pada papan bagian kepala; 6) memastikan punggung balita tetap menempel pada papan pengukur; 7) meluruskan kaki balita dan menekan lututnya sedemikian sehingga lutut dan betis bagian belakang menempel dengan papan pengukur; 8) memposisikan telapak kaki balita tegak lurus dengan alas papan pengukur; 9) menarik papan bagian kaki hingga menyentuh telapak kaki balita tegak lurus; 10) membaca dan mencatat hasil pengukurna hingga ketelitian $0,1 \mathrm{~cm}$. 
5. Pengukuran tinggi balita yang sudah bisa berdiri menggunakan microtoise. Pengukuran ini terdiri dari 15 langkah, yakni 5 langkah pada tahap pemasangan alat dan 10 langkah pada tahap pengukuran. Kelima langkah pada tahap pemasangan antara lain: 1) memilih dinding yang rata dan tegak lurus dengan lantai sebagai tempat dipasangnya alat microtoise; 2) memeriksa dan memastikan bahwa bagian dinding yang rata tersebut lebarnya tidak kurang dari lebar bahu orang yang akan diukur; 3) meletakkan microtoise di lantai, rapat dengan dinding, kemudian menarik pita microtosie hingga skala pada microtoise menunjukkan angka nol ; 4) memastikan pita microtoise tertempel dengan baik dan tidak bergeser-geser. Langkah-langkah pengukuran terdiri dari: 1) mencari tempat yang tepat dengan lantai yang rata, dinding yang lurus sehingga pertemuan antara lantai dengan dinding membentuk 90 derajat; 2) menempelkan microtoise dengan paku di dinding setinggi 2 meter dengan melihat angka nol pada skala; 3) meminta klien melepas alas kaki, topi dan aksesoris lainnya; 4) meminta klien berdiri di bawah microtoise dengan membelakangi dinding; 5) meminta klien berdiri tegak dengan lutut emnempel serta ujung tumit, betis, pantat, punggung, belakang kepala menempel pada dinding; 6) meminta klien agar pandangan lurus ke depan sehingga membentuk Frankfurt plane horizontal; 7) meminta agar lengan klien di samping badan dengan rileks dengan telapak tangan menghadap ke paha; 8)meminta klien untuk menarik nafas yang panjang; 9) menarik headboard hingga menyentuh ujung kepala; 10) membaca dan mencatat hasil pengukuran.

Tabel 1. Daftar Tilik Observasi Penilaian Keterampilan dan Penetapan Skornya

\begin{tabular}{|c|c|c|c|}
\hline Jenis Pengukuran & Tahapan & Skor & Total \\
\hline Penimbangan berat badan bayi menggunakan & Pemasangan alat & 1 & \multirow{2}{*}{6} \\
\hline baby scale & Pengukuran & 5 & \\
\hline Penimbangan berat badan balita menggunakan & Pemasangan alat & 7 & \multirow{2}{*}{12} \\
\hline dacin & Pengukuran & 5 & \\
\hline Penimbangan berat badan balita menggunakan & Pemasangan alat & 1 & \multirow{2}{*}{7} \\
\hline timbangan injak & Pengukuran & 6 & \\
\hline Pengukuran panjang badan bayi dan balita yang & Pemasangan alat & 1 & \multirow{2}{*}{10} \\
\hline belum bisa berdiri mengggunakan length board & Pengukuran & 9 & \\
\hline Pengukuran tinggi balita yang sudah bisa berdiri & Pemasangan alat & 5 & \multirow{2}{*}{15} \\
\hline menggunakan microtoise & Pengukuran & 10 & \\
\hline & \multicolumn{2}{|c|}{ Total Skor } & 50 \\
\hline
\end{tabular}

(Sumber: Positive Deviance Resource Centre, 2017)

Keterampilan dibagi menjadi dua kategori: 1) baik apabila melakukan secara benar $\geq 80 \%$ tahapan pengukuran atau mencapai skor $40 ; 2$ ) kurang apabila melakukan secara benar $<80 \%$ tahapan pengukuran atau mencapai skor $<40$ (Kemenkes, 2011a). Kedua instrumen telah divalidasi di lokasi yang berbeda dengan lokasi studi.

Materi penyuluhan dan pelatihan meliputi: peran kader dalam pemantauan pertumbuhan bayi dan balita, informasi yang diperoleh kader selama posyandu, status gizi anak usia 0 - 60 bulan, menghitung umur anak, pengukuran antropometri yang meliputi: berat bayi 0 - 6 bulan dengan baby scale, panjang badan dengan lengthboard, berat balita dengan dacin, dan tinggi balita dengan microtoise. Penyuluhan dilakukan dengan presentasi 
dan pemutaran video pengkuran antropometri. Pelatihan dilakukan dalam kelompok kecil berjumlah 2-3 orang di mana masing-masing kelompok dipandu oleh narasumber dibantu oleh 2 mahasiswa program studi gizi Fikes Uhamka semester 6 yang telah lulus matakuliah penilaian status gizi.

\section{Analisis Data}

Data dianalisis dengan perangkat lunak pengolah data SPSS for windows versi 22. Data yang dianalisis meliputi data karakteristik kader (frekuensi dan proporsi) serta data nilai pre-post pengetahuan dan keterampilan (mean, maksimal dan minimal). Data univariat disajikan dalam bentuk tabel untuk menyajikan karakteristik kader. Analisis bivariat dilakukan dengan paired $t$ test untuk melihat peningkatan pengetahuan dan keterampilan sebelum dan sesudah penyuluhan dan keterampilan.

\section{HASIL DAN PEMBAHASAN}

\section{Karakteristik Subjek}

Karakteristik kader posyandu yang menjadi subyek penyuluhan diperoleh melalui wawancara menggunakan kuesioner. (Seluruh kader posyandu Kenanga 1 dan Kenanga 2 Cilandak Barat yang berjumlah 15 orang mengikuti penyuluhan dan pelatihan ini hingga selesai. Seluruhnya berjenis kelamin perempuan dengan umur termuda adalah 31 tahun dan umur tertua adalah 75 tahun. Hampir separuhnya (46,67\%) sudah menjadi kader selama $\geq$ 10 tahun, dengan kader terlama adalah 38 tahun sedangkan terbaru adalah 1 tahun. Sebagian besar (73\%) kader adalah tamatan SLTA, di mana pendidikan terendah adalah tamatan SLTP dan kurang dari 10\% kader tamatan perguruan tinggi (D3/S1). Seluruh kader pernah mendapatkan penyuluhan maupun pelatihan dengan beragam jenis. Sebanyak 53,3\% kader pernah mendapatkan pelatihan pencatatan data kohort posyandu, sebanyak 33,3\% kader pernah mendapatkan pelatihan tentang perilaku hidup bersih dan sehat (PHBS), dan sebanyak 13,3\% pernah mendapatkan penyuluhan tentang kesehatan gigi dan mulut. Namun, tidak ada satu pun kader pernah mendapatkan pelatihan tentang antropometri. Seluruh data karakteristik kader disajikan dalam tabel 2.

Tabel 2. Karakteristik Kader

\begin{tabular}{lcc}
\hline \multicolumn{1}{c}{ Variabel } & \multicolumn{2}{c}{ Distribusi Frekuensi } \\
\cline { 2 - 3 } & Jumlah (n) & Proporsi (\%) \\
\hline Umur & 2 & 13,3 \\
$\quad<39$ tahun & 6 & 40,0 \\
$40-49$ tahun & 7 & 46,7 \\
$\quad \geq 50$ tahun & & $51,00 \pm 11,04$ \\
$\quad$ Rerata \pm SD & & \\
Pendidikan Terakhir & 3 & 20,0 \\
$\quad$ SMP & 11 & 73,3 \\
SMA/SMK & 1 & 6,7 \\
D3/S1 & & \\
Lama menjadi kader posyandu & 4 & 26,7 \\
$\quad<5$ tahun & 4 & 26,7 \\
$5-9$ tahun & 7 & 46,7 \\
$\quad \geq 10$ tahun & & 66,7 \\
Frekuensi Mengikuti Pelatihan Kader & 10 &
\end{tabular}




\begin{tabular}{lll}
$3-4$ kali & 2 & 13,3 \\
$\geq 5$ kali & 3 & 20,0 \\
Jenis Pelatihan yang Pernah Diikuti & & \\
Pencatatan & 5 & 53,3 \\
PHBS & 8 & 33,3 \\
Kes. Gigi & 2 & 13,3 \\
\hline
\end{tabular}

\section{Kegiatan Penyuluhan dan Pelatihan}

Kegiatan dimulai dengan pengisian daftar hadir dan biodata kader. Setelah seluruh kader hadir, dimulailah pretest untuk menilai tingkat pengetahuan tentang pengukuran antropometri bayi dan balita.

Setelah mendapat penyuluhan, maka selanjutnya narasumber memandu kader dalam praktik pengukuran. Terdapat 3 pos pengukuran, yakni: pengukuran berat badan dengan timbangan injak, pengukuran berat badan dengan dacin, pengukuran tinggi badan dengan microtoise dan pengukuran panjang badan dengan lengthboard.
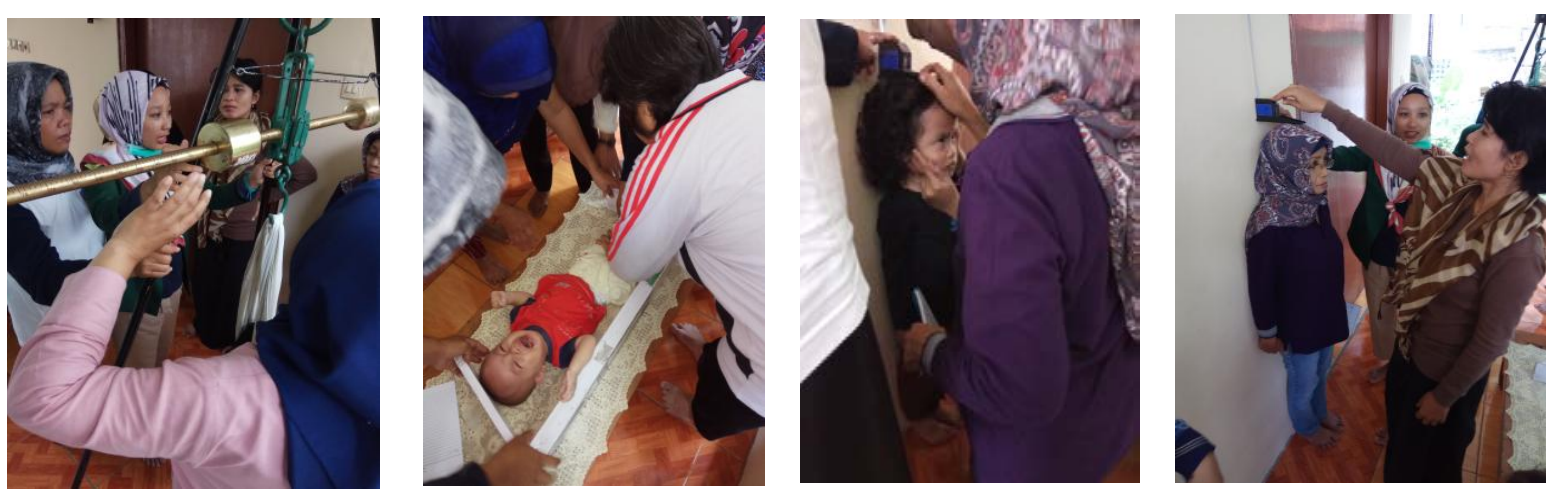

Gambar 1. Praktik Pengukuran Antropometri

\section{Peningkatan Pengetahuan}

Sebelum dilakukan penyuluhan, hanya separuh responden $(53,3 \%)$ yang memiliki pengetahuan baik dengan rata-rata skor 11,13 . Setelah diberikan penyuluhan, lebih dari tiga perempat responden (80\%) memiliki pengetahuan baik dengan rata-rata skor 14,67. Peningkatan pengetahuan dapat dilihat pada gambar 1 . Hal ini penunjukkan adanya peningkatan skor sebesar 3,54. Analisis statistik dengan paired t-test menunjukkan bahwa peningkatan tersebut signifikan dengan $P$ value 0,001 (tabel 3). Hal ini menunjukkan bahwa penyuluhan yang dilakukan terbukti meningkatkan pengetahuan kader posyandu dalam melakukan antropometri bayi dan balita.

Tabel 3. Skor Pre-Postest Pengetahuan dan Keterampilan Kader

\begin{tabular}{cccc}
\hline Variabel & $\begin{array}{c}\text { Pretest } \\
(\text { Mean } \pm \text { SD) }\end{array}$ & $\begin{array}{c}\text { Postest } \\
(\text { Mean } \pm \text { SD) }\end{array}$ & P Value \\
\hline Pengetahuan & $11,13 \pm 2,774$ & $14,67 \pm 2,895$ & 0,001 \\
Keterampilan & $26,59 \pm 3,796$ & $39,00 \pm 3,185$ & 0,001 \\
\hline
\end{tabular}

Hasil ini sejalan dengan penelitian Laraeni \& Wiratni (2014) di wilayah kerja Puskesmas Dasan Cermen Mataram yang juga membuktikan peningkatan proporsi kader dengan pengetahuan baik dari 5\% menjadi 39\% setelah dilakukan penyegaran mengenai penimbangan dengan dacin. Begitu juga dengan penelitian Sianturi (2012) di wilayah kerja 
Puskesmas Jatinegara yang juga membuktikan peningkatan signifikan rata-rata skor pengetahuan dari 12,68 menjadi 36 (p value=0,000). Begitu pula dengan Penelitian Lubis dan Syahri (2015) di wilayah kerja Puskesmas Desa Lalang dan Tuntungan Kota Medan yang menunjukkan peningkatan signifikan rata-rata skor pengetahuan sebesar 2428 point ( $\mathrm{p}$ value $=0,0001)$.

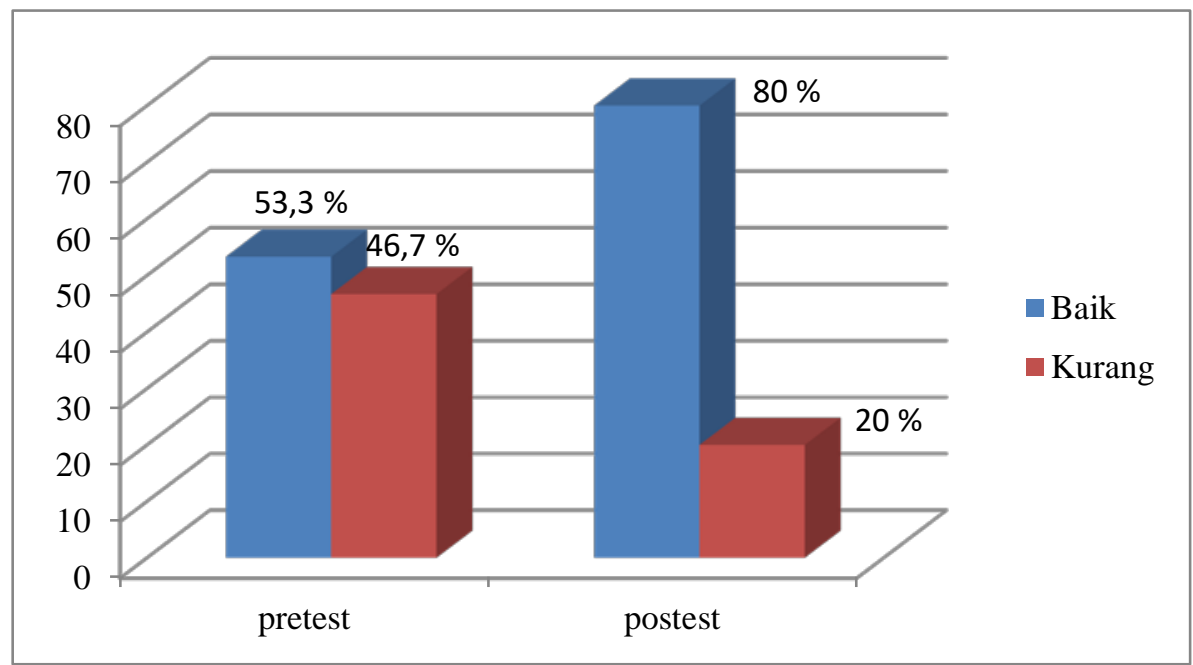

Gambar 2. Pengetahuan Kader Sebelum dan Sesudah Penyuluhan

Meningkatnya proporsi kader berpengetahuan baik setelah penyuluhan dipengaruhi oleh berbagai faktor, baik dari segi komunikator, komunikan maupun media edukasi. Menurut (Broom \& Cutlip, 2006), keberhasilan penyarapan suatu informasi dipengaruhi oleh: 1) Kredibilitas, hal ini terkait kepercayaan komunikan terhadap komunikator. Dalam hal ini kader posyandu menaruh kepercayaan besar kepada tim yang merupakan akademisi dari Program Studi Gizi Fikes Uhamka. 2) Konteks, yakni kesesuaian kegiatan dengan situasi dan kondisi yang ada. Dalam hal ini, keiatan penyuluhan dengan media edukasi menggunakan cara belajar orang dewasa sangat sesuai dengan kondisi yang ada, di mana seluruh pembelajar adalah usia dewasa. 3) Konten, yakni kesesuaian materi dengan kebutuhan dan permasalahan mitra. Dalam hal ini, kader mengaku belum pernah mendapatkan penyuluhan terkait antropometri sehingga kegiatan ini sangat dibutuhkan oleh mereka. 4) Kejelasan, yakni terkait isi materi, bahasa, intonasi dan gesture komunikator dalam memberi penyuluhan. Dalam kegiatan ini, tenaga penyuluh adalah dosen Prodi Gizi Fikes Uhamka yang terlatih memberikan edukasi kepada kelompok dewasa. 5) Kemampuan komunikan, yakni terkait karakteristik kader. Sebagian besar kader (80\%) berpendidikan menengah dan tinggi sehingga memudahkan penyerapan informasi (Notoatmodjo, 2010). Selain itu, pengalaman juga memengaruhi penyerapan informasi, di mana hampir separuh (46,7\%) kader telah menjadi kader posyandu selama 10 tahun atau lebih. 6) Saluran distribusi, yakni media edukasi yang digunakan. Pada kegiatan ini, peneliti mendistribusikan booklet berwarna, presentasi menarik dengan layar infocus dan memutar video. Hal ini menunjang penyerapan informasi oleh kader. 


\section{Peningkatan Keterampilan}

Tabel 3 menunjukkan peningkatan rata-rata skor keterampilan dari 26,59 \pm 3,796 menjadi 39,00 $\pm 3,185$. Hal ini menunjukkan terjadi peningkatan skor keterampilan sebelum dan sesudah pelatihan sebesar 12,41. Analisis statistik dengan paired t-test menunjukkan bahwa peningkatan tersebut signifikan dengan $P$ value 0,001 (tabel 3). Tidak adanya kader yang memenuhi skor minimal keterampilan baik sebelum pelatihan disebabkan oleh beberapa faktor yang terkait dengan karakteristik kader itu sendiri, yakni pengetahuan dan pelatihan yang pernah diikuti.

Menurut (Notoadmodjo, Hassan, Hadi, \& Krianto, 2008), pengetahuan atau kognitif merupakan domain yang sangat penting dalam membentuk tindakan seseorang. Seperti diketahui bahwa sebelum penyuluhan hanya separuh kader (53,3\%) berpengetahuan baik. Faktor lainnya adalah pengalaman, yakni pelatihan yang pernah diikuti. Meskipun seluruh kader pernah mengikuti pelatihan, namun tidak ada satu pun pernah mendapatkan materi tentang pengukuran antropometri. Hal inilah yang menjelaskan rendahnya keterampilan kader dalam pengukuran antropometri meskipun hampir separuhnya $(46,7 \%)$ telah menjadi kader selama 10 tahun atau lebih.

Setelah diberikan pelatihan dalam kelompok-kelompok kecil, terjadi peningkatan yang signifikan untuk skor keterampilan. Hal ini sejalan dengan penelitian sebelumnya oleh Sianturi (2012) di wilayah kerja Puskesmas Jatinegara yang membuktikan peningkatan ratarata skor keterampilan $(8,23$ menjadi 9,59; $\mathrm{p}$ value=0,013) pada kelompok perlakuan setelah pelatihan. Begitu juga dengan penelitian Lubis dan Syahri (2015) di wilayah kerja Puskesmas Desa Lalang dan Tuntungan Kota Medan yang menunjukkan peningkatan signifikan rata-rata skor keterampilan sebesar 1071 point ( $p$ value=0,003).

Peningkatan keterampilan ini tidak lepas dari peningkatan pengetahuan. Selain itu, metode pelatihan yang disampaikan cukup sesuai, yakni dalam kelompok-kelompok kecil yang terdiri dari 2-3 orang dengan bimbingan instruktur. Sutiani (2014) menyebutkan bahwa responden wanita lebih membangun komunikasi dengan lebih intim pada kelompokkelompok kecil. Hal inilah yang menyebabkan informasi yang diterima lebih banyak diserap dan retensinya mampu meningkatkan skor keterampilan.

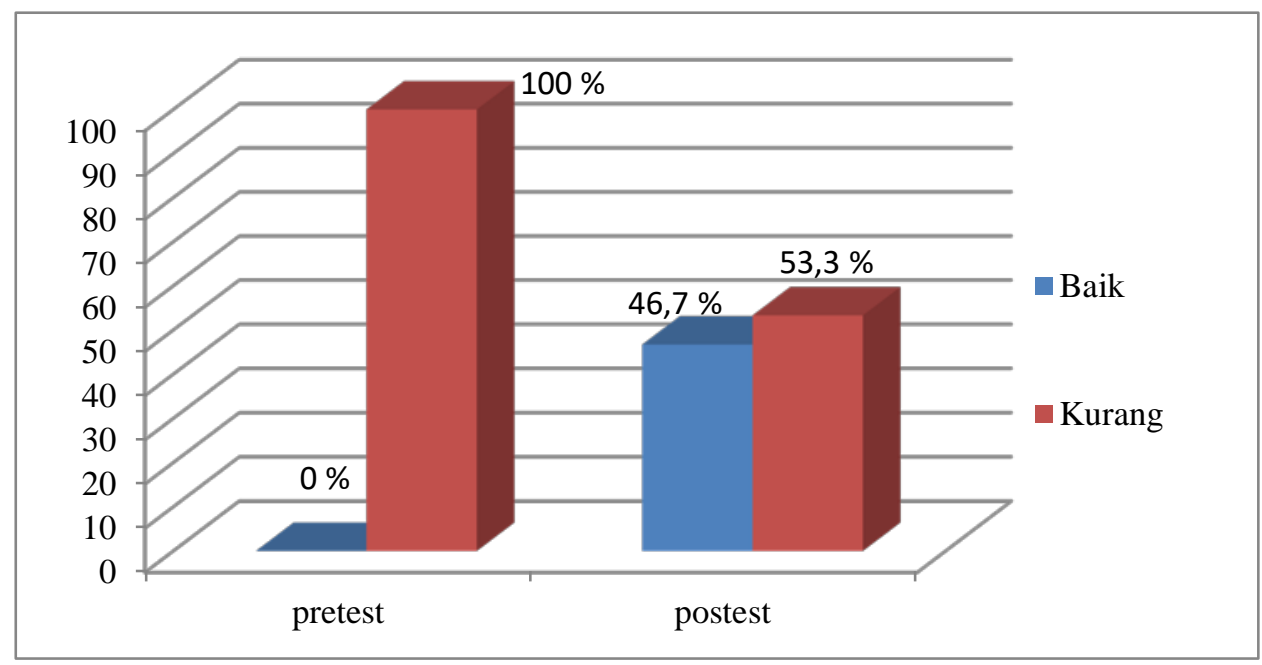

Gambar 3. Keterampilan Kader Sebelum dan Sesudah Penyuluhan 


\section{KESIMPULAN}

Peningkatan pengetahuan dapat dilakukan dengan penyuluhan menggunakan media edukasi seperti booklet, presentasi layar infocus dan video. Peningkatan keterampilan dapat dilakukan setelah penyluhan dengan melakukan pelatihan dalam kelompok-kelompok kecil dengan panduan instruktur. Diharapkan dengan meningkatnya keterampilan dapat dipertahankan dengan praktik yang kontinyu pada bulan-bulan berikutnya saat penimbangan posyandu. Disarankan kepada kader untuk melakukan pengukuran antropometri secara bergilir (rolling) setiap bulannya agar seluruh kader dapat secara kontinyu mempraktikkan semua jenis pengukuran.

\section{UCAPAN TERIMA KASIH}

Ucapan terima kasih terutama ditujukan kepada Lembaga Pengabdian Masyarakat UHAMKA selaku lembaga yang memberi dukungan secara penuh pada kegiatan pengabdian masyarakat ini, baik dari segi bimbingan maupun finansial. Ucapan terimakasih juga kami tujukan kepada seluruh kader Posyandu Kenanga 1 dan 2 Cilandak Barat yang telah berpartisipasi aktif dalam mengikuti pelatihan antropometri hingga selesai.

\section{DAFTAR PUSTAKA}

Arikunto, S. (2002). Metodologi Penelitian. Jakarta: Rineka Cipta.

Broom, G., \& Cutlip, S. (2006). Effective Public Relations (9th ed.). Upper Sadle, New Jersey: Pearson Prentice Hall.

Gandaasri, A. (2017). Gambaran Presisi dan Akurasi Penimbangan Balita Oleh Kader Posyandu di Wilayah Kerja Puskesmas Kecamatan Pesanggrahan Jakarta Selatan Tahun 2017. Universitas Islam Negeri Syarif Hidayatullah Jakarta.

Indriaty, C. (2002). Hubungan Karakteristik Kader Penimbang dengan Presisi dan Akurasi Hasil Penimbangannya di Kabupaten Sukabumi, Bogor, Demak dan Semarang. Universitas Indonesia.

Iswarawanti, D. N. (2010). Kader Posyandu: Peran dan Tantangan Pemberdayaannya dalam Usaha Peningkatan Gizi Anak di Indonesia. Jurnal Manajemen Pelayanan Kesehatan, 13, $169-173$.

Kemenkes. (2011a). Buku Panduan Kader Posyandu: Menuju Keluarga Sadar Gizi. Jakarta: Kementerian Kesehatan RI.

Kemenkes. (2011b). Buletin Jendela Data dan Informasi Kesehatan: SIKDA Generik. Jakarta: Pusat Data dan Informasi Kemenkes RI.

Laraeni, Y., \& Wiratni, A. (2014). Pengaruh Penyegaran Kader terhadap Pengetahuan dan Keterampilan Kader Posyandu Menggunakan Dacin di Wilayah Kerja Puskesmas Dasan Cermen Kecamatan Sandubaya Kota Mataram. Media Bina Ilmiah, 8(4).

Lubis, Zulhaida, \& Syahri. (2015). Pengetahuan dan Tindakan Kader Posyandu dalam Pemantauan Pertumbuhan Anak Balita. Jurnal Kesehatan Masyarakat, 65-73. 
Mahmudiono, T. (2007). Understanding the increased of Child Height for Age Index during the Decline Coverage of Posyandu Using Intrinsic, Extrinsic, and Macroenvironmental Factors Approach. The Indonesian Journal of Public Health, 4(1).

Notoadmodjo, S., Hassan, A., Hadi, E. N., \& Krianto, T. (2008). Promosi Kesehatan di Sekolah. Jakarta.

Notoatmodjo, N. (2010). Promosi Kesehatan, Teori dan Aplikasi. Jakarta: Rineka Cipta.

Positive Deviance Resource Centre, P. (2017). Buku Monitoring Kegiatan Posyandu. Depok: Universitas Indonesia.

Rahayu, S. P. (2017). Hubungan Tingkat Pengetahuan Kader tentang Pengukuran Antropometri dan Keterampilan dalam Melakukan Pengukuran Pertumbuhan Balita di Posyandu Kelirahan Karangasem Kecamatan Laweyan. Universitas Muhammadiyah Surakarta.

Rajagopalan, S. (2003). Nutrition Challenges in the Next Decades. Food and Nutrition Bulletin, 24(3).

Sianturi, Y. (2013). Peningkatan Kemampuan Kader Kesehatan dalam Melakukan Deteksi Tumbuh Kemang Balita melalui Pelatihan. Jurnal Keperawatan, 1(1), 12-19.

Sukiarko, E. (2007). Pengaruh Pelatihan dengan Metode Belajar Berdasarkan Masalah terhadap Pengetahuan dan Keterampilan Kader Gizi dalam Kegiatan Posyandu Studi di Kematan Tempuran Kabupaten Magelang. Universitas Diponegoro.

Sutiani, R. (2014). Gambaran Pengetahuan dan Keterampilan Kader Posyandu dalam Pemantauan Pertumbuhan Bayi dan Balita di Wilayah Kerja Puskesmas Desa Lalang Tahun 2014. Jurnal USU, 1(3). 